\title{
Between the Spirit and the Word: Reading the Gendered African Pentecostal Bible
}

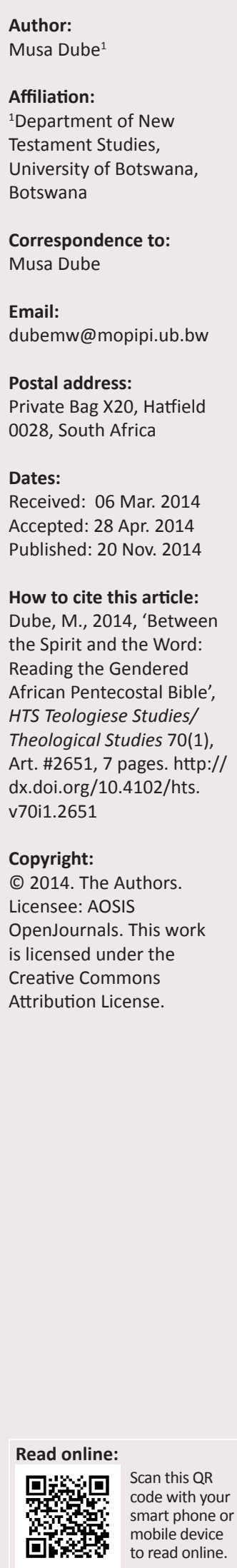

This article reviews the gendered Pentecostal Bible as documented by various researchers. It assesses how the prophetic-spirit framework encounters and functions within the framework of the inerrant but patriarchal written word. The Spirit framework is an oral canon that opens spaces of gender empowerment. Yet Pentecostal scholars problematise the supposedly liberating Spirit, highlighting that it sometimes denies the materiality of human existence and inhabits the constraining parameters of patriarchal church structures. The article suggests that in addition to the Spirit-Word framework, new Pentecostal theological categories, such as healing and deliverance and the prosperity gospel need to be investigated for the new spaces they open for gender justice. 'The authority of the Bible as the word of God, and the experience of the Holy Spirit form two of the most important sources of Pentecostal theology' (Kwabena Asamoah-Gyadu 2004:390).

\section{Introduction}

\section{The Spirit in the Word}

In her article, 'Taking stock and building bridges', Anne Hallum (2003) notes that:

In terms of sheer size, the Pentecostal Movement is probably the most significant religious movement in the world, but what is sometimes overlooked is that it is primarily made up of women. (p. 171)

While her focus is Latin America, researchers from every continent confirm that Pentecostalism is the fastest growing form of Christianity in various continents (Asamoah-Gyadu 2010:238; Meyer 2004; Omenyo 2006; Togarasei, Mmolai \& Nkomazana 2011:120). What kind of hermeneutical frames inform Pentecostal interpretations and what kind of gender relations are constructed in their biblical readings? Do they construct gender relations that are liberating to both sexes, or do they normalise the biblical and cultural patriarchy? In asking these questions, one is stepping into a largely unexplored area. As Madipoane Masenya (2005) and other scholars point out:

Older western Mission-initiated Pentecostal Churches as well as the newer indigenous 'spirit-based' Churches have received little or no attention within the academy, as foci of theological and biblical hermeneutical research. (p. 48)

Exploring the usage of the Bible among Pentecostals, Paul Gifford (2008:205), for example, says neo-Pentecostals have a 'new usage' which is nonetheless 'almost totally ignored in academic discussions.' With a satirical comment on Gerald West and Musa Dube's (2000) volume, Bible in Africa, Gifford (2008:204) suggests that they have missed the 'real Bible in Africa' pulsating in the African Pentecostal charismatic churches. Hallum (2003:169), who investigates Pentecostalism as a form of women's movement, describes the academically under-explored area as a 'deafening silence'. In speaking about the African neo-Pentecostal gendered Bible, we are thus treading on a new research area, with an inadequately analysed (1) gender relations, (2) biblical hermeneutics, and (3) the history of neo-Pentecostal churches among the scholars of religion. ${ }^{1}$ This article will explore how the space between the Spirit and the written word on the issues of gender justice is negotiated among the Pentecostal movements.

Many researchers of African neo-Pentecostal movements underline its democratic style of worship (Asamoah-Gyadu 2005:129-131; Meyer 2004). According to Asamoah-Gyadu (2005) democratic worship is the belief that:

Any individual who has experienced the Spirit is a minister and, therefore, through his or her charisma including natural abilities and talents can minister to others .... This democratisation of charisma or ministry is built on the dominant theological image in Pauline ecclesiology of the church as the 'body of Christ'. Here each member is expected to function in his or her spiritual gift in order that the body can function charismatically (Romans 12:4-8; Ephesians 4:7-16). (p. 130)

1.This statement needs to be qualified; namely, that the research gap in Pentecostal studies exists among African scholars of religion and theology, but thrives in anthropological studies, who have been conducting research for at least two decades now. 
Hallun (2003:173) points out that Pentecostals 'practice participatory worship with singing, testifying, faith-healing, and speaking in tongues.' Gifford (2008:204) underlines the same, holding that the Pentecostals are 'characterised rather by untrammelled exuberance and participation', especially in their worship. Asamoah-Gyadu (2004) holds that:

Charismatic movements generally democratize access to the sacred and emphasize the charismata pneumatika, 'spiritual gifts' as graces that are available to every believer and not just those in the ordained ministry in the church. (p. 391)

And he seemingly suggests that the so-called democratic worship has implications for gender equality.

More research is necessary, however, to explore the relationship between democratic worship and gender equality in the Pentecostal movement, for while 'democratic worship' is often proclaimed by the researchers of some Pentecostal Charismatic Churches (henceforth PCCs), thereby implying some form of freedom and equality in gender, class, ethnicity and age, other research findings suggest otherwise. Sarojini Nadar (2005:74), for example, insists that the PCCs 'are caught between this "democratic" space and their "theological space", which argues that the Bible is the Word of God' (see also Crawley 2008:317). Using the case study of women in her church, the Full Gospel Church, Nadar's research findings indicate that women are still far behind in the numbers of the ordained, even if they have been freed to assume ordained ministry. Nadar's findings are consistent with Musa Dube's (2007) findings in the Botswana, when she notes that:

[W] cannot overlook that even those churches that have a long history ordaining women still have very few of them in the full time ministry. Of note here is the Pentecostal Holiness Church, whose history of women's ordination dates back to 1960, yet there are only four women in the ordained structure. (p. 230)

Ashon Crawley, writing about African American PCC and their ordained women, insists that PCCs are multi-vocal and fluid, but still holds that:

$[A] \mathrm{s}$ a historically male site, the pulpit forces people to judge preachers as to how be male and, as such, masculine they are. Masculinity becomes the standard by which preachers are intelligible. (p. 319; cf. Lekanang 2007)

Hallum (2003:183), who is making a case for Pentecostal space as a woman's place that provides new forms of feminism through networking, nonetheless acknowledges that, 'males hold the titles of leadership and are named preachers in Pentecostal churches.' In short, democratic worship space does not necessarily translate into gender equity in the space of the PCCs, practices and biblical interpretations.

\section{The Spirit and the Word}

This gender tension in the space of the PCCs, that seemingly embraces gender justice while it endorses gender oppression, is apparently framed by their two streams of biblical belief that intersect and dissect into different directions in endless circles. This includes the belief in the Holy Spirit that is poured upon all believers, enabling them to be empowered and to speak and proclaim the gospel to the ends of the earth (Ac $1-2) .{ }^{2}$ It is the latter that often creates apparently 'democratic' forms of worship and enables some denominations to embrace gender justice. On the other hand, the PCCs also believe in the Bible as the inerrant 'Word of God'. The Bible is of course patriarchal and believing in its inerrancy makes room for the side-lining of women. Philomena N. Maura and Damaris Parsitau (2008) capture this tension holding that the PCCs's:

[A]ttitude to the Bible has led to their being labelled fundamentalist. The Bible is their source of authority and doctrine. The Churches use the Bible as a law code and this leads to a legalistic theology. To them the Bible is unerring in every single detail and is to be taken literary. This attitude has implications for issues regarding the place and role of women, marriage, family, sexuality .... A husband is the head and she is expected to defer to him in all matters. (pp. 177-178)

But given the emphasis by PCCs on the Holy Spirit, Maura and Parsitau (2008) also point out the following:

Not only are women there as participants, they have also assumed significant roles as founders and heads of churches. They also function as pastors, healers, and prophetesses. Just like men, they are mediators of God's grace and spirit. Due to their Pentecostal theology that provides avenues for the expression of charismatic gifting irrespective of gender, the attitude to women in these movements have [sic] been positive. For these reasons, it has been suggested that Pentecostal and charismatic movements have transformative effects on women, particularly those in search for equality. (pp. 177-178)

Maura and Parsitau (2008) seem to think the patriarchy of the written word gets the best, thereby overpowering the power of the liberating-spirit. Thus they conclude that:

$[T]$ o the extent that women's roles are circumscribed by a literalist biblical interpretation of their roles and functions, a closer examination of their place in the churches reveals certain handicaps and paradoxes. (p. 178)

They go on to point out that ' $[t]$ hese churches embrace the household codes in the New Testament that prescribe silence of women and apply them literarily in their practice' (Maura \& Parsitau 2008:180). Sarojini Nadar (2005:73), speaking from the experiences of the Full Gospel Church in Durban, is adamant that 'it is not surprising that women in the church are oppressed: This is because the Bible is taken as normative without the acknowledgement that it is a patriarchal document.' Given this tension between the liberating Spirit and the patriarchal oppressive written word among the PCCs, Madipoane Masenya (2005:47-59) has adopted the metaphor of 'a double-edged sword' to speak about the gendered role of the Bible in Pentecostal circles.

\section{Journeys of the Spirit in the Word}

Some historical assessment of this tension is thus in order. In their article, 'Prophetic vs. priestly religion', Charles Barfoot and Gerald T. Sheppard (1980:2-17) assess the changing role

2.One major study that explores the Spirit-Word framework (which I did not have access to prior to writing this article), is that of Born (2009). 
of women clergy in classical Pentecostal churches. Not only do they point out that 'the first person in the movement's genesis to have the experience of the "baptism in the Holy Spirit", as evidenced by glossolalia, was a woman' (Barfoot \& Sheppard 1980:2). They also highlight that two Pentecostal denominations, the Apostolic Faith and the International Church of the Foursquare Gospel, were founded by women. In so doing, Barfoot and Sheppard underline that at the beginning of the 20th century, to which the roots of the current Pentecostal movements are traced, women and men, across the races, were equal participants although within the first two decades signs of strive and gender-biasness began to show its claws. Barfoot and Sheppard employ Weberian theory, which holds that new religions of the oppressed are characterised by gender equality in their beginnings, but the equality hardly lasts beyond the first stages of the formation of such communities. Placing the Pentecostal beginnings within such a framework, Barfoot and Sheppard (1980) find that data from the history of the Pentecostal movement supports Weber's theory. They hold that the beginnings were prophetic and inclusive, but in the later stage the movement became more priestly and less gender-inclusive. To illustrate their point, they use the case of the Assemblies of God and the International Church of Foursquare.

What then is the biblical hermeneutic of the prophetic stage? According to Barfoot and Sheppard (1980):

In the early stages of classical Pentecostalism, ecstatic religious experience was interpreted primarily through the biblical depiction of prophecy and prophetic figures. This distinctly prophetic interpretation of the Pentecostal experience helped establish at least three factors, which were responsible for the equality of the sexes in the early Pentecostal ministry: 1 . The importance of a calling'"' as the only difference between ministers and laity, 2. The confirmation of the call through the recognition of charisma by the community and 3 . The community's eschatological belief that they were experiencing the 'latter rain' (Joel 2:23), in which 'your sons and daughters will prophesy' (Joel 2:28). (p. 4)

Of these three outlined factors, the first and the third factors provide a liberating framework of biblical interpretation in Pentecostal settings, that is, the Holy Spirit framework of reading. Elaborating the prophetic framework of interpretation, Barfoot and Sheppard point out that it was informed by the biblical prophetic figures and how they narrated their stories of assuming public roles. Such stories always had a particular plot, namely hearing a calling from God, giving an excuse or objection, reassurance and commission (Barfoot \& Sheppard 1980:5). Hence biblical stories of Moses, Gideon, Jeremiah and Paul, amongst others, followed the same plot. Their assessment of Pentecostal female leaders indicates that they 'frequently reported that they had objected to God's call on the grounds that they are women' but 'as in the case of Moses and Jeremiah, God overcomes the objection' (Barfoot \& Sheppard 1980:5). Illustrating this pattern, Barfoot and Sheppard examine the story of Aimee Semple MacPherson, the founder of The Church of the Foursquare Gospel, illustrating the prophetic plot in the self-narrated story - from the call to objection until one accepts the role. McPherson received her call as a teenager but, assuming that she was just a woman, she married a missionary instead and raised children. But the call kept pressing on her as she tried to drown it away with housekeeping, raising children and being a wife. In narrating her resistance and final surrender, McPherson notably speaks through prophetic plots of Jeremiah and Jonah. Anna Kubai (2007), the male-oriented self-modelling risk emasculating women, writing about the Pentecostal explosion in postgenocide Rwanda tells of a different biblical model:

A woman Pastor returned to Rwanda says that she has been inspired by the Old Testament story of Deborah. For her (and many others for whom she speaks) restoration and reconciliation include 'restoration of many things that the tradition has taken away from us.' Leadership in the church is one of those things. Women should find solace in a church ... where all are truly children of God. (p. 114)

To return to Barfoot and Sheppard, 'The Last days' perspective also provided for a gender-justice framework of interpretation in the early days of the Pentecostal movements. This framework is drawn from the birthing of the early church, where the Spirit of God was poured 'upon all flesh', enabling 'sons and daughters to prophesy' (Ac 2:118). Barfoot and Sheppard (1980) hold that:

For classical Pentecostals, clear signs that they were living in the last days included not only the speaking in other tongues, physical healings, prophecies and visions, but also women preaching. In interpreting this biblical passage to her college students, Aimee Semple McPherson taught, as did most Pentecostals, that to prophesy was to preach. (p. 9)

A closer look at the 'charisma factor' highlights a closer relationship between the prophetic and last-days perspectives; central to these is the 'spirit or Holy Spirit', that must be demonstrated within a community of believers. Indeed Crawley's (2008:308-329) description of ordained black women, in what he describes as somewhat male space, must assume the masculinity persona in demonstrating their charismatic preaching skills. Yet Crawley's description of the charismatic worship space is quite instructive. Crawley focuses on performance that accompanies the acts of the Spirit, which creates fluidity and multi-vocality. In the energy of the Spirit the pastor may leave the pulpit and join the wider congregation, as they all praise God in joy, dance and clapping or in call and answer participatory preaching. On such occasions, the pastor crosses boundaries, coming down to the people and the Spirit helps people to momentarily disrupt the binary social boundaries of difference as they become one in the Spirit of joyful praise and performance (Crawley 2008:308-329).

Turning to the Botswana context, research on ordained Pentecostal women indicates that 'hearing the call of God' is a central way of reading the Bible in a gender-inclusive manner. Musa Dube's analysis of data, published in Nkomazana (2011), found that ' $[t]$ he language employed by (Pentecostal) women is best described by the sentence "I heard God's call" or "God called me"” (Dube 2007:229). The word of God as heard or spoken by prophets is more than just 
a written word; it is also a heard word. It is an oral word, that while linked to the written word, it is somewhat independent from the written word. It can thus override the written texts, which may insist on non-liberation perspectives. One such typical example was the response of a woman reader to explain her leadership role, while the written word seems to suggest otherwise. The woman answered: 'When God spoke to me, God never opened the Bible' (Dube 2007:210-211). The prophetic-spirit framework thus becomes the second canon, another space, where God liberates the oppressed from the patriarchal restrictions by speaking directly to them, instead of going through the written text. In Dube's (2007) review of Botswana ordained women's response to the call to ordination, she points out that women:

$[H]$ ear God calling them to church leadership. Hearing here underlines these women's oral history in leadership. This strategy seemed to cut across all the three traditions, but it is particularly common among evangelical women. If God calls men and women and if they both hear this call and respond positively... then gender discriminations that are in the society, churches, texts and theology can be carefully sidelined. (p. 235)

\section{Interrogating Spirit moves}

In her paper, 'The sword that heals! The Bible and African women in African-South African Pentecostal Churches', Madipoane Masenya (2005:51-54) identifies four key thematic areas that guide biblical interpretations amongst the PCCs: 'The hereafter', the 'New birth from heaven', 'Spirit baptism' and 'The Bible as wounding sword'. Masenya (2005), herself an ordained minister in a Pentecostal church, holds that 'The hereafter framework' was a colonial missionary-marketed approach, which encouraged people to disregard their present oppression and encouraged them to focus on heaven. It was a perspective that allowed Africans to focus on heaven and disregard their colonial and apartheid oppression. Masenya says the heaven framework is still prevalent amongst many PCCs that reproduce the colonial framework. Although she does not explicitly say so, Masenya's take on the heaven framework suggests that the prosperity and deliverance approach of the current PCCs is a liberating and decolonising approach. Yet her description of the New birth shows that it can be quite some closer to the hereafter perspective since 'Spirit re-born individuals ... live with the promise of an eternity together with Jesus in heaven' (Masenya 2005:52). Turning to 'Spirit baptism' Masenya (2005) holds that it is an:

$[A] c t$ of the Lord Jesus Christ, whereby the newly converted Christian, irrespective of gender, receives the blessings promised to all believers ... whereby the Pentecostal Christian, woman or man, old or young, black or white, poor or rich, is divinely empowered for service both in the church and the world. (p.53; [my emphasis])

Masenya regards the spirit hermeneutic as gender-inclusive and empowering to both sexes. In agreement with Barfoot and Sheppard (1980), Masenya (2005:53) holds that the 'core message of the Holy Spirit's empowerment is particularly

3.See Lekanang (2007) and Berman (2007) for some case studies on Pentecostalism and violence against women. relevant to those who live on the outer margins of the society such as African Women.'

In her article, 'On being the Pentecostal Church: Pentecostal women's voices and visions,' Sarojini Nadar dwells on the prophetic-spirit framework and pushes its boundaries. She interrogates how and why it sometimes succumbs to patriarchal oppression, while endeavouring to articulate a more liberating way of reading the Bible for liberation, through the prophetic-spirit framework. Nadar (2005:67) argues that a 'critical view of the Spirit's role in the Church can help to contribute towards gender transformation.' A critical view entails acknowledging how some 'Spirit' perspectives are in fact contributing towards oppression rather than liberation. This includes the use of the Spirit among the PCCs as an excuse for not studying or analysing their concrete social contexts in biblical interpretation or even that of the text. Some PCCs's ministers claim that they are led by the Spirit. Further, the prophetic-Spirit framework, she argues, is also used to create a dichotomy that separates the Spirit from material and social issues. The latter can lead the oppressed, especially abused women, to tolerate their oppression, while focusing on things of the Spirit, not flesh. Nadar is adamant that it allows PCCs's biblical readers to disregard many forms of social oppression, such as race and gender discrimination. She insists that these limited perspectives of the Spirit lead to limited interpretations of the scriptures and are 'inadequate for emancipation of women' (Nadar 2005:67).

Nadar thus suggests that the way forward in discerning the liberating Spirit is first to acknowledge the limiting perspectives and then to articulate a more liberating perspective of reading the scripture through the Spirit. Asserting that we 'we need to first understand how the Spirit reads Scripture,' Nadar (2005) provides us with some guiding ethical questions. She asks:

Can the way in which the Bible is used to discriminate against women be described as Spirit-inspired interpretation? What defines Spirit-inspired interpretation? ... The question is: Can an interpretation that results in the deaths of women who are already victims of abuse, be an interpretation of the Spirit? I suggest not.... The Spirit that gives life surely cannot read the text in a way that leads to destruction, and surely cannot read. (p. 73)

Nadar (2005) concludes that in order for the Spirit hermeneutical framework to work efficiently:

$[W]$ e need to move beyond a one-dimensional understanding of the Spirit to one where by the Spirit can be felt in multifaceted ways with an over-riding concern for the preservation of life. (p. 74)

In arguing that the validity of a liberating-Spirit-reading will be measured by its impact on improving the quality of life, Nadar (2005:65) is consistent with Masenya (2005) who also concludes that the use of the Bible to oppress women or any person:

[C]ontradicts the liberating nature of the mission of the Church as Christ body on earth. Its mission is meant to bring life not death, healing rather than suffering, freedom rather than bondage. (p. 453) 


\section{Sociology of the Prophetic-Spirit framework}

According to Barfoot and Sheppard (1980), the Spirit framework characterises the beginnings of the Pentecostal movements, attested by inclusivity to various classes, races and gender. With time, the communities shift allegiance away from the Spirit framework towards the written word, more structured organisation and simultaneously reduced or even curtailed women's empowerment. They call this the priestly stage. Barfoot and Sheppard (1980) use the story of Assemblies of God and McPherson, the founder of The Foursquare, to illustrate the point. Assemblies of God's structural growth, from a fluid sect, was marked by a gradual reduction of women's participation in full ministry, characterised by adoption of various policies and resolutions, which was sealed in a 1930 Council meeting, ironically through Reverend Robert Brown, who was married to one of the most influential woman minister then. Apparently Brown (Evangel 1931:5, cited in Barfoot \& Sheppard 1980) said he:

[C]ould not help noticing that in the scriptures there was no woman in the priesthood and none in the apostolic ministry. God chose men. He stated that his wife was always refrained from 'acts of priesthood'... He said he hated to see women put on white garments and try to look like angels, and go into the baptismal pool to baptize converts. (p. 14)

Barfoot and Sheppard (1980:14) point out that thus 'the resolution passed which, in essence denied the earlier right of women to priestly acts in the church. Male monopolisation of the priestly functions was now complete.' Capturing the patriarchalisation of the movement, one member of the Assemblies of God described the movement as having 'begun as an orphan girl who had now grown "to be a mighty man"'(Barfoot \& Sheppard 1980:14). Barfoot and Sheppard (1980:14) underline that the marginalisation of women was also accompanied by the separation of ways between races. The honeymoon was over. Meanwhile McPherson, who had formed her own church, insisted that as long as she lived the door would remain open for women wishing to go into ministry. But she was notably a doorkeeper in recessional space against the full embracement of women - a recession that would last for the longest time among classical Pentecostal churches.

Musa Dube's (2007:210-236) review of ordination of women among classical Pentecostal churches in Botswana confirms that the Spirit is often subject to the scriptures and their institutionalised structures; the prophetic space is subject to the priestly space, or the two remain in a perpetual tug of war. Dube (2007) thus concludes that:

It would seem that while women can become ministers through hearing and accepting God's call, their ordination to full ministry is still dependent on whether the institution of the church allows for the ordination of women. A good example is the Apostolic Faith Mission in Botswana (AFM), only began ordaining women in the mid-nineties. AFM, however, had been accepting and sending women who said they had God's call to Bible School for training. Upon completion, however, they were relegated to Sunday school ministry (children's). (p. 230)
Similarly, women from the Family of God Pentecostal church were subjected to institutionalised patriarchal discrimination. Dube (2007) writes:

The women who accept the call are subjected to gendered training. For example, at the Bible College, Massie was trained in a secretarial course, then she was attached to the prophet's wife for mentoring. Upon her return, she was assigned to a ministry that deals with women only. Similarly, in her narration of her call and her response, More Manka of Family of God, reported undergoing a secretarial course. (p. 231)

The Spirit may and actually does open doors for women empowerment, but clearly several hurdles come up in varied forms as described by Nadar and the above-cited institutional patriarchal strategies. Masenya (2005:54) thus points out that 'Pentecostal Church leaders and Christians in general can use the Bible, albeit at times in good faith, to undermine God's purposes towards believers.' In such cases, Masenya speaks of 'The Bible as a Wounding Sword' that teaches the poor to embrace their poverty, women to tolerate oppression and gender-based discrimination amongst the Pentecostal communities. Has the aggressive and innovative neo-Pentecostal movement ushered in another Spirit age with their prosperity and deliverance message? More research is needed on the latter, nevertheless implications can be drawn.

\section{Deliverance from patriarchal generational curses unto prosperity}

Much ground has been covered in defining and naming the space between the Spirit and the Word, as the borderlands, where perpetual battle for gender justice is fought in the Pentecostal movements. The above writers give us the history and sociologies of journeys of the Spirit and the Word in liberating genders. Writers interrogate how and why the Holy Spirit collaborates in gender oppressive agendas such as dissuading people from embracing material conditions of their lives or being subject to patriarchal word and institutions. They investigate how the Spirit has also provided an escape valve, allowing women to stake their claims for power in a third unwritten canon of the Holy Spirit; how the Holy Spirit inspires performance, a space where gender, sexuality and other social differences cross into each other's boundaries and provides for the humanity of all; and how the attractiveness of the Pentecostal movement to women provides a space for women's networking thus creating room for transformative coalitions between women of different classes.

In addition, two other aspects of neo-Pentecostal practice need to be recognised for their potential in strengthening the space for gender justice. I refer here to the practice of deliverance and the gospel of prosperity. In his article, 'Mission to set the captives free: Healing deliverance and generational curses in Ghanaian Pentecostalism', Asamoah-Gyadu (2004:389), who associates deliverance with 'The rise of Pentecostal/ Charismatic movement in African countries', holds that it is one of the 'new ways of dealing with challenges of life.' Deliverance has a specific purpose according to AsamoahGyadu (2004), it seeks to: 
[S]et people free, that is, physically, emotionally, economically and spiritually, so that they may be restored to proper functioning $\ldots$ and enabled to enjoy the fullness that Jesus promises to all who come to him. (p. 399)

Asamoah-Gyadu (2004:394) explains that healing and deliverance means being freed from demonic influences and curses so that people may enjoy 'health and wholeness'. He explains that:

[I]f a person is oppressed demonically ... there are inexplicable problems at every turn: frequent illness, unemployment, poverty, business and academic failures, inexplicable deaths in a family, and so on. (p. 395)

This outline indicates that the purpose of deliverance is therefore to set the Christian free from both supernatural powers of evil and concrete social oppressive structures.

One example of structural oppression discussed by AsamoahGyadu (2004) is the case of 'shrine slavery' (trokosi) practiced among the Ewe of Ghana and explains that:

Young girls were offered as 'vestal virgins' by their families to live in servitude in traditional shrines as wives of gods, and by extension wives of traditional priests, who are custodians of the shrines. (p. 399)

They were offered 'to atone for the transgressions of their ancestors' (Asamoah-Gyadu 2004:399). Unfortunately, though:

[T] he submission of the virgin links the cursed family and their descendants in perpetual bondage to the shrine, that is if she dies the family is obliged to replace her with another virgin. (p. 399)

In the Ghanaian Pentecostal theology shrine slavery is regarded as a generational curse that can be remedied through healing and deliverance, given that deliverance seeks to liberate and restore a born-again Christian to experience the 'fullness of life in Christ'. According to Asamoah-Gyadu (2004):

[T] he idea behind the African Christian response is that even the 'taboo-ed' persons like Trokosi and Osu should not be tabooed forever. That is how 'healing and deliverance' hermeneutic reads the manifesto of Jesus in Luke 4:18. Through its ministry of healing and deliverance, African Pentecostal/Charismatic Christians see their mission in continuity with the ministry of Jesus, as encapsulating the preaching of good news to the poor, the proclamation of freedom for prisoners and recovery of sight to the blind, and the release of those who are oppressed. (p. 401)

The elaboration places the healing and deliverance hermeneutic within the larger hermeneutic of liberation. It follows that if deliverance rescues all captives from both oppressive supernatural and social structures of evil, the ministry of deliverance opens up other spaces for all captives to go free. This has implications for the search for genderjustice in the Pentecostal space. Womenfolk have lived under the yoke of patriarchal oppression from generation to generation - oppressed and marginalised on the basis of their gender. Patriarchal oppression passes as a generational curse. The patriarchal generational curses - that perpetually discriminate against women on the basis of their gender need to be exorcised from the Pentecostal structures and theology, and wherever they manifest in the society. Women should experience total freedom under the Pentecostal ministry of healing and deliverance.

Prosperity is one of the innovative theologies of the contemporary Pentecostal movement. Underlying its centrality, Birgit Meyer (2004:459) says that in PCCs 'prosperity and being born-again are held to be two sides of the same coin.' Many other Pentecostal researchers have underlined the centrality of prosperity by characterising PCCs's teaching as a gospel of 'health and wealth' (Dilger 2007:66; Kubai 2007:200; Togarasei et al. 2011:120). In Southern Africa the prosperity gospel is best captured by the popular chorus, 'Everything will double double: Your house will double double; your cars will double double.' Yet prosperity is not only about material gain. It is about the total deliverance of a person to live an abundant life. AsamoahGyadu (2007:393) makes a link between deliverance and prosperity holding that ' $[w]$ hen healing and deliverance takes place, prosperity, in terms of abundant life in Christ and success in [the] material world, is what African Pentecostals believe follows the believer.' Brigit Meyer's (2004) research findings are consistent, pointing out that:

Because the devil is supposed to operate not only through blood ties linking people to their extended family, in particular, and local culture, in general... the prospect of prosperity is made to depend on deliverance. (p. 461)

A great deal of women's oppression has been dependent on denying them access to material wealth. Over many centuries women had access to property through their fathers, husbands and sons. Without material rights a person loses their human dignity and the power to make a decision about their own lives. Disassociating women from property has been one of the most powerful patriarchal tools for keeping women subjugated and oppressed - under some form of generational curse of perpetual dependence and poverty. Given that the neo-Pentecostal movements' theology underlines deliverance and the prosperity gospel, women in these movements need to claim this hermeneutical space for gender empowerment and liberation from all forms of oppression.

\section{Acknowledgements}

\section{Competing interests}

The author declares that she has no financial or personal relationship(s) that may have inappropriately influenced her in writing this article.

\section{References}

Amanze, J., 1998, African Christianity in Botswana: The case of African Independent Churches, Mambo, Gweru.

Asamoah-Gyadu, K.J., 2004, 'Mission to set free: Healing deliverance and generational curses in Ghanaian Pentecostalism', International Review of Mission 95(370/371), 389-406. http://dx.doi.org/10.1111/j.1758-6631.2004.tb00468.x

Asamoah-Gyadu, K.J., 2005, African charismatics: Current developments within Independent Indigenous Pentecostalism in Ghana, Brill, Leiden.

Asamoah-Gyadu, K.J., 2007, 'Pulling down strongholds: The Evangelicalism, principalities and powers and the Pentecostal Imagination', International Review of Mission 96(382/383), 306-317. http://dx.doi.org/10.1111/j.1758-6631.2007. tb00612.

Asamoah-Gyadu, K.J., 2010, 'Religious Education and Religious Pluralism in the New Africa', Religious Education 105(3), 238-244. http://dx.doi. org/10.1080/00344081003771925 
Barfoot, C. \& Sheppard, G., 1980 'Prophetic vs. Priestly: The changing role of women clergy in classical Pentecostal churches', Review of Religious Research 22(1), 2-17. http://dx.doi.org/10.2307/3510481

Berman, S., 2007, Batswana men's interpretation of Hosea 1-3: A case study of Africa Evangelical Church, University of Botswana, Gaborone.

Born, J.B., 2009, 'Worlds of the Spirit: African spiritual and Pentecostal Churches relations in Botswana', PhD thesis, University of South Africa.

Crawley, A.T., 2008, 'Let's get it on! Performance theory and Black Pentecostalism' Black Theology: An International Journal 6(3), 308-329. http://dx.doi. org/10.1558/blth2008v6i3.308

Dilger, H., 2007, 'Healing the wounds of modernity: Salvation, community and care in a Neo-Pentecostal Church in Dar Es Salaam, Tanzania', Journal of Religion in Africa 37, 59-83. http://dx.doi.org/10.1163/157006607X166591

Dube, M.W., 2007, 'God never opened the Bible to me: The role of women in Botswana Churches,' in F. Nkomazana (ed.), Church History of Botswana, pp. 210236, Cluster, Pietermaritzburg.

Gifford, P., 2008, 'The Bible in Africa: A novel usage in Africa's new Churches', Bulletin of SOAS 71(2), 203-219.

Hallum, A.M., 2003, 'Taking stock and building bridges: Feminism, women's movement, and Pentecostalism in Latin America', Latin American Review 38(1) 169-186. http://dx.doi.org/10.1353/lar.2003.0008

Kubai, A., 2007, 'Post-genocide Rwanda: The changing religious landscape', Exchange 36, 198-214. http://dx.doi.org/10.1163/157254307X176606
Lekanang, O., 2007, 'Comparative readings of Botswana and Western feminist scholars of Judges 19: Reading for women empowerment', MA Dissertation, University of Botswana.

Meyer, B., 2004, 'Christianity in Africa: From African Independent to PentecostalCharismatic Churches', Annual Review of Anthropology 33, 447-474. http:// dx.doi.org/10.1146/annurev.anthro.33.070203.143835

Masenya, M., 2005, 'The sword that heals! The Bible and African women in African/ South African Pentecostal Churches,' in I.A. Phiri \& S. Nadar (eds.), On being Church: African women's voices and visions, pp. 47-59, WCC, Geneva.

Maura P.N. \& Parsitau, D.S., 2008, 'Perceptions of women's health and rights in Christian New religious movements in Kenya,' in A. Adogame (ed.), Christianity in Africa and the diaspora: The appropriation of a scattered heritage, pp. 175-186, Continuum, London.

Nadar, S., 2005, 'On being Pentecostal Church: Pentecostal women's voices and visions,' in I.A Phiri \& S. Nadar (eds.), On being Church: African women's voices and visions, pp. 60-79, WCC, Geneva.

Nkomazana, F., 2011, 'The Botswana religious landscape,' in J. Amanze, F. Nkomazana \& O.N. Kealotswe (eds.), Biblical Studies, theology, religion and philosophy: An introduction for African Universities, pp. 313-342, Zapf Chancery, Eldoret.

Omenyo, C.N., 2006, Pentecost outside Pentecostalism: A study of the development of Charismatic renewal in the mainline churches in Ghana, Boekencentrum, Zoetermeer.

Togarasei, L., Mmolai, S. \& Nkomazana, F (eds.) 2011, The faith sector and HIV/AIDS in Botswana: Responses and challenges, Cambridge Scholars Publishing, Cambridge.

West, G. \& Dube, M.W. (eds.), 2000, The Bible in Africa: Transactions, trajectories and trends, Brill, Amsterdam. 